\title{
PEMBERDAYAAN PERAN PEREMPUAN DI MASA PANDEMI COVID19 PADA BANK PEMBANGUNAN DAERAH KALIMANTAN SELATAN
}

\author{
Ningrum Ambarsari, Adwin Tista, Salamiah \\ Fakultas Hukum, Universitas Islam Kalimantan \\ Email : ningrum74fhuniska@gmail.com
}

\begin{abstract}
ABSTRAK
Mengingat bahwa diskriminasi terhadap perempuan yang melanggar azas persamaan hak antara laki-laki dan rasa hormat terhadap martabat manusia, merupakan halangan bagi kedudukan perempuan, atas dasar persamaan dengan kaum laki-laki dalam kehidupan. Secara umum kondisi perempuan Indonesia mengalami perubahan sebagaimana yang tampak dalam laporan statistik tentang peningkatan pendidikan dan kedudukan perempuan dalam sektor publik. Namun demikian, di tengah-tengah budaya dominan Indonesia yang bersandar pada nilai-nilai patriarkhi, perubahan kondisi ini tidak berbanding lurus dengan perbaikan posisi perempuan di masyarakat. Perempuan masih merupakan kelompok pinggiran dalam lingkaran pengambil keputusan.
\end{abstract}

\begin{abstract}
Given that discrimination against women violates the principle of equal rights between men and respect for human dignity, it is an impediment to women's standing, on the basis of equality with men in life. In general, the condition of Indonesian women has changed as seen in the statistical report on improving education and the position of women in the public sector. However, in the midst of Indonesia's dominant culture that relies on patriarchal values, this change in conditions is not directly proportional to the improvement of women's position in society. Women are still a fringe group in the decision-making circle.
\end{abstract}

\section{PENDAHULUAN}

Dalam konteks demokrasi jelas posisi ini tidak menguntungkan perempuan sistem nilai patrirkhi menempatkan perempuan berada di bawah subordinasi laki-laki. Sistem patriarkhi dapat ditemui dalam kehidupan sehari-hari, baik pada perempuan kelas bawah maupun kelas atas. Di rumah di tempat kerja, dan komunitas yang lebih luas. Hal yang serupa juga dikatakan oleh Saparinah
(Kompas, 2002 : 5), yaitu ketakutan dan keraguan anggota parlemen laki-laki mengenai gagasan peningkatan keterwakilan perempuan menunjukan tiga hal : Pertama, mereka menganggap rendah kemampuan dan potensi perempuan dalam politik, Kedua, mereka tidak memahami bahwa perempuan mempunyai pengalaman yang berbeda dengan laki-laki yang diperlukan dan yang berguna dalam suatu proses demokratis. Ketiga, mereka 
takut disaingi perempuan bila jumlahnya dalam usaha mikro dan kecil diperbankan.

Yang menjadi mitra adalah Bank pembangunan Daerah kalimantan Selatan . Dimana tugas keseharian mereka cukup padat di kantor, ditambah lagi perannya dalam keluarga yang semakin sedikit waktu yang dimiliki (data awal pengabdian). Sehinngga perlu adanya FGD yang tujuannya untuk memberdayakan secara maksimal peran mereka ditempat kerja. dan luar tempat kerja yakni sebagai ibu bagi dan istri di ranah domestik keluarga.

Di masa Pandemi Covid19 yang dilakukan pihak perbankan adalah mengurangi jam operasional pekerjanya yang biasanya jam operasional dimulai pada pukul 08.00 sampai dengan pukul 16.00 selama Pandemi Covid19 berubah menjadi dimulai pukul 08.30 sampai dengan pukul 02.30.

Adapun unit yang ada pada Bank Kalsel A.Yani (kancab) ada 3 unit yaitu pelayanan nasabah, pelayanan pinjaman dan pelayanan operasional, Ketiga unit ini setiap bulannnya mendapat pelatihan dari kantor pusat melalui virtual dengan durasi waktu 2 jam pertemuan. Untuk mentukan bisa atau tidaknya mengikuti pelatihan ada beberapa kriteria yang harus dipenuhi yang dilihat dari prestasi kerja seperti service excellent dan prestasi sebagaimana merujuk pada SOP kebijakan dalam operasional pada Bank Kalsel.

Adapun yang yang menjadi produk pada bank kalsel Ayani adalah konvensional, tabungan, deposito, kredit (ada kredit dengan agunan dan tanpa agunan). Permasalahan yang dihadapi oleh bank konvensional bukan sekedar persoalan bunga, akan tetapi menyangkut seluruh sistem perbankan mulai penarikan dana dari masyarakat sampai kepada prinsip kehati-hatian yang berkelebihan menjadi bank konvensional berada dalam situasi yang dilematis. Sehingga keterlibatannya di dalam upaya penanggulangan kemiskinan hanya dapat dilakukan secara optimal, apabila bank sudah dapat mengandalkan penerimaannya dari pendapatan-pendapatan non bunga seperti fee atas jasa perbankan .

Sehubungan dengan hal tersebut, maka yang menjadi kendala-kendala yang dialami perempuan adalah Masalah pendidikan, pekerjaan, jender, peran domestik (urusan rumah tangga), budaya partriarkhi, dan hubungan kekeluargaan serta kendala-kendala yang bersifat umum. 
1) Masalah Pendidikan

Pendidikan bagi perempuan merupakan kekuatan yang dapat meningkatkan taraf hidupnya ke tingkat yang lebih baik, karena dengan pendidikan perempuan dapat berjuang melaksanakan programprogram partai. Pendidikan adalah suatu hal yang sangat urgen untuk melakukan suatu tindakan yang bermakna bagi dirinya sendiri maupun terhadap suatu usaha perekonomian yang mereka perjuangkan.

Suatu hasil penelitian menunjukkan bahwa pemberian kesempatan yang lebih besar kepada perempuan untuk memperoleh pendidikan, secara umum menghasilkan peningkatan "sharing" kekuasaan dalam keluarga, peningkatan pekerjaan dalam profesi, penurunan tingkat fertilitas, dan peningkatan kedudukan dalam kegiatan sosial ekonomi kerakyaratan (Smock, 1997).

2) Masalah Keadilan dan Kesetaraan Gender

Ini merupakan suatu kendala yang banyak dialami oleh perempuan dalam berkiprah di bidang usaha perbankan yang terkait dengan perekonomian rakyat, sebab selama ini perempuan sangat tertekan oleh pihak-pihak yang berkepentingan untuk melenserkan sekaligus menghilangkan posisi perempuan diberbagai bidang misnismen.

3) Masalah Peran Domestik (Rumah Tangga)

Peran dan fungsi perempuan adalah juga bersifat kodrati (refroduktif), peran ekonomi (produktif), dan peran sosial (kemasyarakatan didasarkan pada kodrat perempuan yang mengarah kepada aspek biologis (Rasdiyanah, 1999:4). Begitu pula halnya dengan perempuan yang terlibat dalam bidang bisnismen yang bermitra dengan usaha perbankan syariah tidak luput dari urusan rumah tangga meskipun telah menjadi bisnismen, sehingga adanya hambatan yang dialami perempuan mungkin saja terjadi, baik dalam rumah tangga maupun dalam bidang usaha perekonomian yang bermitra usaha dengan perbankan syariah.

4) Masalah Budaya Patriarkhi

Adat istiadat ada kaitannya dengan peran perempuan dalam perbankan syariah hal ini berkaitan dengan keberadaan perempuan sebagai ibu 
rumah tangga. Hal ini menunjukkan bahwa betapa sulitnya posisi perempuan dalam rumah tangga, sehingga mampu memposisikan kedua kegiatan tersebut tanpa mengabaikan aspek keluarganya. Kramarae dan Paula (1985:223), dalam bukunya A Feminist Dictionary menjelaskan bahwa patriarkhi merupakan term yang penting yang digunakan sebagai cara untuk mengelaborasi tertindasnya perempuan berdasarkan struktur dan susunan masyarakat. Ideologi ini dibangun berdasarkan kekuatan laki-laki, sebagai simbol prinsif laki-laki dan kekuasaan ayah, serta sebagai kontrol laki-laki terhadap seks dan pikiran-pikiran perempuan.

Sistem patriarkhi merupakan suatu mekanisme yang lebih banyak menempatkan laki-laki pada posisi kunci atau peranan yang lebih dominan. Sistem tersebut terutama menempatkan status dan peranan perempuan di bawah perwalian laki-laki. Konsekuensinya kemudian adalah semakin terbatasnya kesempatan dan akses perempuan dalam urusan-urusan yang berkaitan dengan aktivitas publik (public sphere), lebihlebih dalam wilayah politik, perempuan hanya berada dipinggiran (periphery zone). Bagi perempuan untuk menjadi bagian dari kelompok elit politik sangat terjanggal dan penuh rintangan kultural.

Sistem patriarkhi yang telah disosialisasikan sejak perempuan lahir hingga dewasa, perlahan tapi pasti membentuk konsep diri pada perempuan itu sendiri. Mereka menjadi tidak siap memimpin, tergantung dan menjadi manusia nomor dua dalam masyarakat. Perempuan menjadi prioritas kedua dalam berbagai hal termasuk bidang usaha mikro dan kecil. Sebagai bangsa yang telah meratifikasi hak-hak usaha perempuan (UU No 68 tahun 1958) dan konvensi penghapusan segala bentuk diskriminasi terhadap perempuan (CEDAW) melalui UU No 7 tahun 1984, pada akhirnya belum cukup membantu dalam menghadapi pemilu 1999 lalu. Waktu setahun terlalu pendek untuk menghapuskan apatisme dan membangun posisi tawar perempuan yang selama puluhan tahun direntankan terhadap intimidasi politik. Waktu setahun juga teramat singkat untuk menghapus stigma yang dilekatkan pada perempuan, perempuan hanyalah sebagai alat untuk melanggengkan kekuasaan yang refresif (Kompas edisi 7 Oktober 1998). 
Kebijakan pemerintah orde baru yang berkuasa waktu itu juga menempatkan perempuan hanya sebagai isteri dan ibu, konsep peran ganda, pengukuhan konsep panca tugas wanita yang dioperasionalkan melalui organisasi-organisasi bentukan pemerintah seperti dharma wanita atau PKK, sistem politik yang birokratis, sentralistik dan militeristik, selama 32 tahun tersebut merupakan beberapa sebab yang menghambat kedudukan usaha perempuan (kompas,12 Agustus 1999).

Dari gambaran di atas jelaslah bahwa minimnya jumlah perempuan di parlemen merupakan hasil dari perjalanan sejarah perempuan itu sendiri yang telah dipinggirkan dari wilayah ini sejak awal perkembangan perempuan. Posisinya yang selalu dibuat tergantung pada laki-laki sebagai hasil dari budaya patriarki menjadi kurang dapat diperhitungkan, dianggap tidak mampu menghadapi persoalan-persoalan besar yang dianggap sebagai wilayah laki-laki, apalagi dalam masalah usaha mikro dan kecil yang penuh ketidakjelasan, seolaholah hanya lakilaki yang bisa memasuki wilayah ini.

Kebijakan-kebijakan pemerintah juga menguatkan posisi tawar perempuan khususnya pemerintahan orde baru, yang melalui kebijakan serta programnya telah membentuk perempuan terus berada di bawah kendali laki-laki dengan gaya patriarkinya. Ini membuat seolah-olah elegitimasi pengekangan perempuan dalam wilayah domestik dan sekalinya diberi kesempatan untuk masuk dalam wilayah bisnismen hanya dijadikan alat untuk kepentingan.

\section{SOLUSI}

Bagaimana metode meningkatkan pemberdayaan peran perempuan di masa Pandemi Covid 19 pada Bank Kalimantan Selatan.

Berdasarkan rumusan masalah maka solusi yang dilakukan adalah melakukan Forum Diskusi (FGD) untuk meningkatkan pemberdayaan peran perempuan dimasa Pandemi Covid19.

\section{HASIL}

\section{PELAKSANAAN}

\section{KEGIATAN}

Kegiatan pelaksanaan PPM masa Pandemi Covid 19 pada Bank Kalimantan Selatan dilakukan dalam dua tahapan, hal ini dilakukan untuk melihat bagaimana kegiatan PPM itu berpengaruh sebelum dan sesudah kegiatan itu dilaksanakan. 
Hasil yang didapatkan adalah sebagai berikut :

1. Sebelum kegiatan PPM dilakukan (kegiatan yang kami lakukan adalah FGD dengan pimpinan unit setiap divisi pada Bank Kalsel) ada keberpihakan terhadap tugas tugas yang diberikan kepada setiap karyawan dengan melihat gender. Hal ini karena mengkhawatirkan bahwa perempuan tidak dapat melakukan tugas yang biasanya dikerjakan para kaum laki-laki terlebih dalam pengambilan keputusan dalam hal ini sebagai contoh pemberian kredit, biasanya bagian yang memutuskan didominasi kaum laki-laki tetapi setelah adanya FGD maka kaum perempuan pun punya kesempatan untuk menempati posisi tersebut tentu saja ada syarat dan ketentuan yang harus dipenuhi.

2. Sebelum kegiatan PPM dilakukan perekrutan sebagai ka unit Divisi dirahasiakan dan setelah kegiatan dilaksanakan lebih transparan sejauh memenuhi kriteria yang berlaku.

Pemberdayaan peran perempuan di masa Pandemi Covid 19 pada Bank Kalimantan Selatan melalui pelatihan pengembangan diri pada divisi masing masing dengan melihat pada:

- Masalah pendidikan, pekerjaan, gender, peran domestik (urusan rumah tangga), budaya partriarkhi, dan hubungan kekeluargaan serta kendalakendala yang bersifat umum

- Masalah Keadilan dan Kesetaraan Gender

Ini merupakan suatu kendala yang banyak dialami oleh perempuan dalam berkiprah di bidang usaha perbankan yang terkait dengan perekonomian rakyat, sebab selama ini perempuan sangat tertekan oleh pihak-pihak yang berkepentingan untuk melengserkan sekaligus menghilangkan posisi perempuan diberbagai bidang bisnismen.

- Masalah Peran Domestik (Rumah Tangga)

Peran dan fungsi perempuan adalah juga bersifat kodrati (refroduktif), peran ekonomi (produktif), dan peran sosial (kemasyarakatan didasarkan pada kodrat perempuan yang mengarah kepada aspek biologis 
(Rasdiyanah, 1999:4). Begitu pula halnya dengan perempuan yang terlibat dalam bidang bisnismen yang bermitra dengan usaha perbankan syariah tidak luput dari urusan rumah tangga meskipun telah menjadi bisnismen, sehingga adanya hambat an yang dialami perempuan mungkin saja terjadi, baik dalam rumah tangga maupun dalam bidang usaha perekonomian yang bermitra usaha

- Masalah Budaya Patriarkhi

Adat istiadat ada kaitannya dengan peran perempuan dalam perbankan syariah hal ini berkaitan dengan keberadaan perempuan sebagai ibu rumah tangga. Hal ini menunjukkan bahwa betapa sulitnya posisi perempuan dalam rumah tangga, sehingga mampu memposisikan kedua kegiatan tersebut tanpa mengabaikan aspek keluarganya.

Dalam hal prestasi kerja ntuk meningkatkan kemampuan manajerial masing-masing divisi biasanya akan dipantau dari service excellent (pelayan terbaik kepada nasabah). Kemudian pihak kantor pusat akan mengirimkan undangan untuk mengikuti pelatihan yang dilakukan secara virtual (online) dengan durasi 2 jam setiap pertemuan yang dilakukan sekali dalam sebulan dan berkelanjutan.

Untuk produk-produk yang ada di Bank Kalsel Syariah antara lain produk Syariah, tabungan, deposito, giro dan pemberian kredit (ada yang dengan jaminan ada dan ada yang tanpa jaminan.tentu saja sesuai dengan SOP (Standar Operasional Prosedur) Kebijakan.

Jam Operasional Selama masa pandemic Covid19 waktu operasional yang biasanya mulai pukul 08.00 dan berakhir pada pukul 16.00 berubah menjadi pukul 08.30 dan berakhir pada pukul 14.30. Hal ini tentu saja bukan berarti pelayanan menjadi kurang maksimal tetapi untuk mengurangi pelayanan offline dan meningkatkan pelayanan virtual.

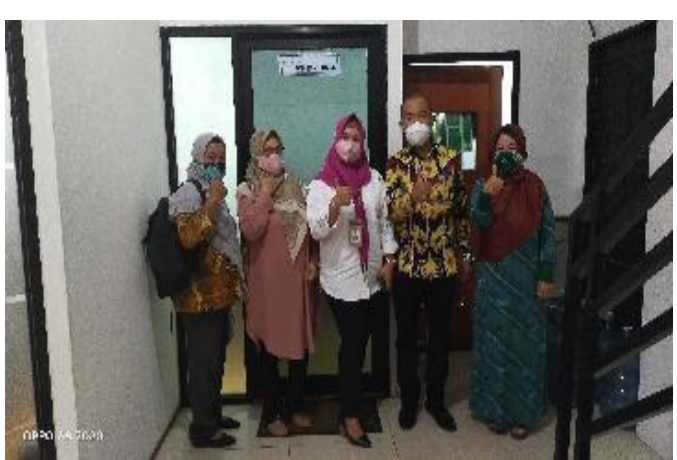




\section{KESIMPULAN}

Kesimpulan

a. Sebelum kegiatan PPM dilakukan (kegiatan yang kami lakukan adalah FGD dengan pimpinan unit setiap divisi pada Bank Kalsel) ada keberpihakan terhadap tugas tugas yang diberikan kepada setiap karyawan dengan melihat gender. Hal ini karena mengkhawatirkan bahwa perempuan tidak dapat melakukan tugas yang biasanya dikerjakan para kaum laki-laki terlebih dalam pengambilan keputusan dalam hal ini sebagai contoh pemberian kredit, biasanya bagian yang memutuskan didominasi kaum laki-laki tetapi setelah adanya FGD maka kaum perempuan pun punya kesempatan untuk menempati posisi tersebut tentu saja ada syarat dan ketentuan yang harus dipenuhi.

b. Sebelum kegiatan PPM dilakukan perekrutan sebagai ka unit Divisi dirahasiakan dan setelah kegiatan dilaksanakan lebih transparan sejauh memenuhi kriteria yang berlaku.

Saran

a. Kegiatan PKMS yang tim kami lakukan diharapkan bisa diterapkan pada intitusi yang lain, dalam artian dengan diadakannya FGD (Focus Group Discusion) maka lebih membuka cakrawala berpikir dalam pengambilan keputusan bahwa kaum perempuan juga dapat melakukan tugas yang biasanya dilakukan kaum laki-laki sebagai penentu kebijakan.

b. Sebaiknya kegiataan PPM ini mendapat dukungan terutama dalam hal pendanaan pada institusi kegiatan dilakukan agar kegiatan menjadi lebih maksimal.

\section{DAFTAR PUSTAKA}

Aisyah, Hamid Baidlowi, Perempuan di Parlemen dan Strategi Peningkatan Kedudukan dan Keterwakilannya, Lokakarya Nasional, 25 Januari 2003 di Jakarta.

Alfiaturohmaniah, Siti., 2003. Ketika Perempuan Memasuki Peran Pablik, Jurnal Suara Merdeka, sabtu 13 Juli 2003. copyright,@ 1996. SUARA MERDEKA.

Alfian, 1988. Pemikiran dan Perubahan Politik Indonesia, Jakarta: LP3E.

Aminy, Aisyah. 2003. Perempuan dalam Pemilihan Umum 2004. (artikel dari internet: www.kompas.co.id.

Anwar, Ahyar. 1999. Kedudukan Politik Dalam tatanan Politik Baru (Studi Tentang Kedudukan Politik di Sulawesi Selatan), Ujung Pandang; Program Pascasarjana UNHAS. 
Anonim, 1995. Sensivitas Gender, Bahan Penelitian Gender, Yogyakarta: PKBI-DIY.

Anshori S, Dadang. 1997. Membincangkan Feminisme: Refleksi Muslimah atas Peran Sosial Kaum Wanita, Cet. I; Pustaka Hidayah, Bandung.

Baharsyah, Justika S. (1999), Мепијu Masyarakat yang Berketahanan Sosial Pelajaran dari Krisis, Departemen Sosial RI, Jakarta .

Budhiati, Ida. 2002. Kuota Perempuan dalam UU Politik, artikel dari inetnet : nasionalm@polarhome.com.
Dian, Kartika Sari, Peran dan Kedudukan Perempuan dalam Otonomi Daerah, Lokakarya Nasional, 24-25 Januari 2002 Hotel Indonesia Jakarta.

Djaenabong, dkk. 1996. Jender dan Pembangunan di Sulawesi Selatan, Ujung Pandang: DPW Puslit IKIP Ujung Pandang.

Fakih,Mansour (1998). Diskriminasi dan Beban Kerja Perempuan Persfektif Gender dalam Bainar (Ed) Wacana Perempuan dalam Keindonesiaan dan Kemodernan, CIDES dan UII Jakarta. 